\title{
Foucault's Turn From Phenomenology: Implications for Dance Studies
}

\author{
Sally Ann Ness
}

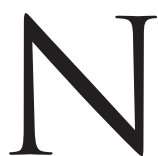

o critic of phenomenology, arguably, has been more influential in prefiguring recent discourses on power, gender, and sexuality that have emerged in dance studies in recent decades than the philosopher-historian-critic Michel Foucault. The number of dance scholars directly citing Foucault, and the number influenced indirectly by his ideas through intermediary theorists such as Judith Butler-perhaps the single most popular one-is so large as to require an essay of its own just to survey. Virtually every analysis of choreographic practice that has addressed these topics since the 1980s has drawn directly or indirectly on Foucault's theories. Indeed, the very mention of the term "discipline" in current dance scholarship (and many related fields as well) more or less automatically makes reference to Foucault's genealogical study of incarceration, Surveiller et punir. Naissance de la prison, translated into English as Discipline and Punish: Birth of the Prison, and, in particular to the chapter, "Les corps dociles" or "Docile Bodies" (Foucault 1975, 137-171; 1975/1995, 135-170). ${ }^{1}$

It might seem, in this regard, that any critical reappraisal of phenomenology as it relates to the intellectual study of dance would be inclined to take its cue from Foucault. This purports to be a somewhat complicated prospect, however, as opinions diverge regarding the precise character of Foucault's relation to phenomenological inquiry generally, and to specific phenomenological philosophers in particular. Foucault made intensive studies of various phenomenologists during the early years of his academic career-Jean-Paul Sartre, Maurice Merleau-Ponty, Martin Heidegger, Edmund Husserl, and the phenomenologically oriented work of Georg Wilhelm Freidrich Hegel. He developed markedly different relations to the work of each, with Heidegger having, perhaps, the most lasting presence. Two of Foucault's first publications were written (arguably) from phenomenological points of view. However, the leading philosophical interpreters of Foucault's work concur that Foucault's critique of phenomenology, once it did emerge, was both fundamental and enduring. This was a critique that focused specifically on the phenomenological conception of the human subject.

The emergence of Foucault's critique occurred between the years of 1954 and $1962 .^{2}$ At this time, Foucault's publications evidence a decisive turn away from phenomenology, one that was

Sally Ann Ness is professor of anthropology at the University of California, Riverside. Her research focuses on semeiotic theory, movement analysis, posthumanist and postphenomenological theories of space and place, touristic performance, and dance ethnography. Her publications include Body, Movement, and Culture: Kinesthetic Symbolism in a Philippine Community (1992); Migrations of Gesture, co-edited with Carrie Noland (2008); "Bouldering in Yosemite: Emergent Signs of Place and Landscape," in American Anthropologist, vol. 113, no. 1 (2011); and "Choreographies of Tourism in Yosemite Valley; Rethinking 'Place' in terms of Motility," in Performance Research, vol. 12, no. 2 (2007). 
articulated, perhaps, most explicitly in the final chapters of his first bestselling text, Les Mots et les choses (1966b), translated into English as The Order of Things. After this critical formulation, Foucault began to develop his archaeological and, later, his genealogical methods of investigating the social production of knowledge, and continued, in one way or another, to move away from phenomenological orientations, particularly those of Husserl, Sartre, and Merleau-Ponty.

Although his work later took a number of theoretical, disciplinary, and philosophical twists and turns, and although Foucault was, by some accounts at least, "haunted" by Hegelian phenomenological discourse long after he overtly moved away from it (Macey 1993, 150-151), ${ }^{3}$ Foucault was never to return to either the mainstreams or the margins of phenomenological investigation. Even at the end of his life, when his views on the self and its experience began to move in new and strikingly different directions from those that defined his earlier theoretical critiques, phenomenology was never to be reviewed, rethought, or reassessed-let alone redeemed—by Foucault, at least not explicitly. His early rejection, particularly of the phenomenology that had dominated French intellectual life from the 1930s through the 1950s, stood the test of time in the evolution of his own thought. As philosopher Todd May has commented, "It is not an exaggeration to say that although Foucault's work goes through methodological changes, it always defines itself against phenomenology" (2005, 285, emphasis in the original). ${ }^{4}$

It is the first task of this essay to review Foucault's initial rejection of the phenomenological subject. Foucault's specific reasons for this rejection-his dissatisfaction with the phenomenology in which he was initially so immersed, as well as the precise direction of the new course he set in having made it - are both at issue here. The second task of this essay is to consider what the implications might be for dance studies of Foucault's turn away from phenomenology. What price, if any, stands to be paid by the field in following Foucault's lead—specifically, the "early Foucault's" lead—away from phenomenology and toward the subjectively decentered social critique that is set forth in Les Mots et les choses, further explicated in L'Archéologie du savoir (The Archaeology of Knowledge) and carried on into Surveiller et punir?

James Miller, one of Foucault's several biographers, has noted that Foucault's work, while it has been enormously influential in a wide array of both academic and practical fields, has been hotly contested in virtually every one of them $(1993,18)$. Gutting concurs, noting that, particularly in the discipline of history, Foucault's work is judged, even by its supporters as "seriously wanting" (2005a, 50). Dance studies, however, appears to be something of an exception in this regard. Its critical theory has, for the most part, not been critical of Foucault. Even when it has, its criticisms would hardly fit the label, "heated."5 This might well be seen as a curious state of affairs, given that, of all the fields in which Foucault's work has met with contestation, none was potentially more foreign to his own understanding, or more marginal to the development of his critical theory, than dance.

To take a brief biographical detour along this line, Foucault's individual affinity for the subject matter of dance was, to put it mildly, minimal. His personal expertise-practical or academicwith any of its more elaborate forms was nonexistent. As he himself repeatedly emphasized, he was, body and mind, a creature whose "natural habitat" was a library, not a studio, and definitely not a concert stage (Macey 1993, 74). ${ }^{6}$ He proclaimed himself to be a being who loathed spending time and/or energy "in nature," a realm that apparently included the motile dimensions of his own organism (Macey 1993, 74). While biographical speculation offers little more than vague suggestion, ${ }^{7}$ Foucault, as the oldest son of a notable French provincial bourgeois family, would seem to have lived through a childhood and youth in which academic studies dominated his life. Little time, energy, or interest was left to develop pursuits that cultivated bodily practices of any elaborately motile sort, dance among them (Eribon 1991, 4-14; Macey 1993, 1-20). Aside from an interest in riding his bicycle, Foucault's life as a motile human being seems to have been muted. ${ }^{8}$ 
This assessment, of course, is not intended as a criticism of Foucault's life history, nor is it meant to suggest that his actual life experiences necessarily foreclosed the development of theoretical projects that might have addressed dance explicitly in some insightful way. Most emphatically, it is not intended to suggest that, had Foucault been more involved with dance or other motile practices, such an involvement necessarily would have guaranteed his development of a significant theoretical discourse on dance. The information, such as it is, is presented here because it provides one possible basis for explaining the circumstance that, while music, painting, theater, and literature were arts that compelled Foucault's sustained and serious attention, Foucault had virtually nothing to say, or think, evidently, about dance-at least nothing that went into print. This was the case even when its consideration would seem to have compelled his attention for his own purposes. ${ }^{9}$

In sum, if the notion of the episteme could be taken to an idiosyncratic level (which of course, by definition, it cannot), Foucault's authorial a priori body of ideas was evidently unmotivated to determine with any certainty any concept of dance that was of any intellectual merit. The subject did not signify as such in Foucault's imagination of modernity. It apparently could not be thought-or was not worth thinking about explicitly-in relation to modernity's conception of the human being, the character Foucault identified as "l'homme" or "man." This may have been because he held the art in low esteem. However, it seems more plausible to suppose that dance was simply not related to those life experiences that exerted a formative experience on his work. ${ }^{10}$

In this respect, the likelihood that Foucault's rejection of phenomenology would result in an approach, or series of approaches, that would be ideally suited to the special problems of dance and choreographic analysis seems rather low. Yet, no serious contestation has emerged from within the field (granted, some are now beginning to be imported from related disciplines). This absence of any heated, dance-centered, critical response to at least the early Foucault might be explained cynically as an indicator of the intellectual weakness of dance theorists, who simply do not have the philosophical or historiographical integrity to do more than echo obligingly Foucault's critical perspectives and the subsequent analytical moves they generate. Alternatively, however, it may indicate that Foucault's archaeological and genealogical projects and interests somehow still are aligned, and profoundly so, with those of dance studies. These possibilities are best considered in the wake of a review of Foucault's early critical turn away from phenomenology-the phenomenology that he considered to be his main intellectual heritage.

\section{The Turn}

As indicated above, there are at least two aspects to Foucault's early rejection of phenomenology. The first is Foucault's move away from the phenomenological subject. The second is a simultaneous, but quite distinct, move toward what might be termed a conceptualist philosophical orientation. Both are important for understanding the implications of Foucault's critique of phenomenology for dance inquiry.

\section{Foucault's Move Away}

With regard to the first aspect, the move away-the key element that repelled Foucault in his rejection of phenomenology, as mentioned above-was the specific conception of the individual modern human subject on which phenomenological investigation, in his view, was founded, and which held supreme importance for modern thought. This human subject Foucault described in some detail in Les Mots et les choses, the text in which, as May has observed, most of Foucault's later references to his rejection of phenomenology are made $(2005,304) .{ }^{11}$ In the final chapters of this text, Foucault wrote of the modern subject:

... modernity begins when the human being begins to exist within his organism, inside the shell of his head, inside the armature of his limbs, and in the whole 
structure of his physiology; when he begins to exist at the centre of a labour by whose principles he is governed and whose product eludes him; when he lodges his thought in the folds of a language so much older than himself that he cannot master its significations, even though they have been called back to life by the insistence of his words. $(1966 / 1973,318)^{12}$

The human subject of phenomenology, this organismically discrete individual that Foucault argued was only conceivable within the intellectual movements of modernity, depended for its intelligibility on one all-important characteristic: its finiteness. Modern man, whatever else he might be, was a being conceived with a lifespan that was not infinite, either spatially or temporally. Foucault argued: "... modern man ... is possible only as a figuration of finitude. Culture can conceive of man because it conceives of the finite on the basis of itself" $(1966 / 1973,318) .{ }^{13}$ Foucault rejected this non-infinite/finite human subject, defined by its organism, labor, and speech, as the starting point for his own inquiry.

Most basically, the implications of the Foucaultian turn away from phenomenology for dance inquiry begin with this definition of the phenomenological subject. To follow Foucault is (1) to accept his claim that an analytics of finitude does indeed define the human subjects of dance since the dawn of modernity and (2) to reject such a finite subject as a viable starting point for critical analysis. Obviously, the latter implication depends upon the former, and it is the former that will be taken up in what follows. However, the appeal of Foucault's early theories for dance theorists may to some extent be understood in relation to the latter.

It should also be noted that Foucault's rejection of the phenomenological subject was justified in terms that narrowed its definition, even further than that which can be seen as emerging from modernity's analytics of finitude alone, and it did so with a specific program of research in mind. In the 1971 preface to the original English edition of The Order of Things, Foucault articulates explicitly this justification. The text reads:

If there is one approach that I do reject, however, it is that (one might call it, broadly speaking, the phenomenological approach) which gives absolute priority to the observing subject, which attributes a constituent role to an act, which places its own point of view at the origin of all historicity - which, in short, leads to a transcendental consciousness. It seems to me that the historical analysis of scientific discourse should, in the last resort, be subject, not to a theory of the knowing subject, but rather to a theory of discursive practice. (1966/1973, xiv)

In this passage two related points bear mention. First, it is not simply a finite, organisimically individual, laboring, speaking human subject per se that provokes Foucault's dissatisfaction. It is an observing subject of this finite type, and it is its observational capability that makes possible its character as a knowing, intelligent subject. The rejected subject of phenomenology is a subject engaged in observational activity. It is a subject whose actual experience (another target of Foucault's critique) is defined by activity that leads to the knowledge of observed objects and to the consequential attainment of objective consciousness.

One must ask, in this regard, what are the implications of projecting this observing, object-oriented, finite modern subject onto the character of a dancing human being, or a choreographing figure, or a human being that is basically in performance? The object-oriented identity may well be apt for the definition of a scientist subject-a character whose purpose is to achieve consciousness of objects as they truly are. This sort of observationally preoccupied human subject, however, would seem basically ill-suited to typify the subjectivity of the dancing human being. If the human being in dance is not fundamentally observational or objectively driven, but nonetheless intelligent in some other sense-perhaps in a sense that is neither subjectively nor objectively delimited, as Mark Franko 
has suggested (Franko, 2011) ${ }^{14}$ - then the Foucaultian category of the (rejected) knowing subject would seem to lose much of its purchase for dance inquiry.

Here, then, is a foundational issue raised by this subject-focused aspect of Foucault's antiphenomenological turn: the issue of whether the activities of objective knowledge-seeking, undertaken by a human being whose identity has been conceived within an analytic of finitude, best define the intelligent human beings of dance. If they do not-and it would seem that in many, if not most cases, they do not-then the analysis of dance would seem to be distorted from the start by the employment of a Foucaultian anti-phenomenological perspective. The theoretical project of conceiving of an alternative to the object-observing subject-one that might give priority to performative in contrast to observational activity-would appear to be a more apt project for critical analysis to undertake.

The second point that bears mention in the passage quoted from The Order of Things is that Foucault's own rejection of the subject of phenomenology hinges on that subject's inappropriateness for analysis of scientific discourse that is historical in orientation-his own particular research interest. It is an interest that he will broaden in subsequent work to include other historical analyses of other discursive formations as well. The importance of this historical orientation cannot be overstated in terms of its influence on Foucault's theoretical approach. In Foucault's perspective, as philosopher Alan Shrift has aptly characterized it, human experience, including bodily experience, is "thoroughly historicized" $(2006,57)$. History is given priority in any investigation of human experience. The transcendental subject of phenomenology that Foucault rejects is, in brief, replaced by a subject that is inconceivable until some context that is historically situated endows it with definition. History, as both a subject and a discipline, has a guiding role to play in Foucault's approach. It is not a simple, pre-critical notion of history, to be sure, nor is it one that fails to recognize the discontinuities of past events and the inherent tendency of narrative to under-represent such discontinuities. Nonetheless, Foucault's approach is historical in its basic character, giving priority to relationships between the present and the past.

In this specific regard, it is most critical to pose the following question: What are the consequences of giving unqualified priority to forms of analysis that foreground historical phenomena and historical processes in the intellectual study of dance? To follow Foucault away from phenomenology, in this regard, is not simply to recognize that dance and choreographic subject matter generally have historical, temporally invested dimensions. Foucault's archaeological and genealogical approaches make much stronger claims than this. It is to posit that the historical aspects of dance and choreography are the key to critical insight. The disciplinary alignment privileges absolutely an historical perspective, even if it is only to critique what that perspective might illuminate.

To follow Foucault's lead, in this regard, is to forego analyses that would give priority to the identification of that which is definitively emergent or categorically ahistorical in choreographic performance. It would preempt analyses that seek to orient to the immanent and the manifesting, as well as the virtual relations of dance-not only as they bear on histories of the present, but as they might make critically conceivable possible futures of the present as well. Given that dance-making regularly, if not typically, involves the embodiment of creative, imaginary, and even otherwise unactualizable events and processes of being, the commitment to a historically oriented research agenda alone risks narrowing inappropriately the disciplinary perspective. In sum, the replacement of a phenomenological with a thoroughly historicized subjectivity forecloses inquiry into the more radically creative, emergent (and even liberatory and agentive) forms of danced experience and intelligence.

\section{The Move Toward}

In addition to the turn away from the phenomenological subject described above, another motivating influence was also operative in Foucault's critical disengagement with phenomenology. 
A positive influence stemmed from Foucault's enduring association with Georges Canguilhem, the successor of Gaston Bachelard at the Sorbonne and a scholar concerned most centrally with the history and philosophy of the life sciences (May 2005, 302; Rheinberger 2005, 193). This positive influence, personified in the figure of Canguilhem, but extending beyond him as well into a distinct intellectual tradition that included Bachelard, Jean Cavaillès, and others, also carries implications for dance inquiry.

Foucault first encountered Canguilhem in 1945, when, at 19 years of age, he sat for the entrance examination for the Ecole Normale Supérieure (Eribon 1991, 24). Canguilhem was one of two examiners. Both passed Foucault. In 1951, when Foucault took the oral examination for the agrégation-the highest competitive examination in the French system-Canguilhem was again one of his examiners. Again, Foucault's efforts met with Canguilhem's approval (Eribon 1991, 38). Canguilhem later served as the official director for Foucault's doctoral thesis on the history of madness and was one of the examiners of its eventual defense at the Sorbonne in 1961 (Gutting 2005a, 61-64; Macey 1993, 104). Canguilhem's subsequent favorable report on Foucault's thesis secured its approval from the Sorbonne and paved the way for its eventual 1961 publication as Folie et déraison: Histoire de la folie à l'âge classique (eventually translated into English in a much abridged version as Madness and Civilization). Canguilhem also later published Foucault's "Naissance de la Clinique: Une archéologie du régard medical" ("The Birth of the Clinic") in a collection he edited for Presses Universitaires de France in 1963 (Macey 1993, 130).

As this record of involvement indicates, Canguilhem's role in Foucault's intellectual development was direct and substantial. Eribon characterizes their meeting in terms of Foucault having encountered his "destiny" (1991, 24). Canguilhem's critical support for Foucault's work spanned the first two decades of Foucault's career and at several points secured its continuance. As a consequence, it was among Canguilhem's students that Foucault explicitly placed himself (Eribon 1991, 18). ${ }^{15}$ That placement entailed a taking of sides in Foucault's view—sides that positioned him against Jean-Paul Sartre and Merleau-Ponty, among others, and against phenomenology more generally. The sides were defined by interests in the philosophy of experience, meaning, and the subject, on the one hand, and interests in knowledge, rationality, reason, and the history of ideas-often termed "concepts" - and theories on the other. ${ }^{16}$

It was toward Canguilhem's philosophical vision that Foucault turned as, and after, he grew dissatisfied with phenomenology. Foucault adopted Canguilhem's historical works as models for his own archaeologies of the 1960s. As Gutting has observed, the books that made Foucault famous, Naissance de la clinique and, even more so, Les Mots et les choses, both made extensive use of Canguilhem's historical approach (Gutting 2005b, 9).

What Foucault found represented in Canguilhem's work was a clear alternative to phenomenology in one particular respect: it was an emphasis, as Gutting describes it, on "the logic of concepts rather than lived experience as the driving force in human thought" (2005a, 61-64). The concept, for Canguilhem, was the object of inquiry of greatest importance for the historian of science. ${ }^{17}$ Hans-Jörg Rheinberger, in this regard, characterizes Canguilhem as "a master of conceptual landscape painting, both in the foreground and in the distance" $(2005,194)$.

Foucault's anti-phenomenological project, to the extent that it aligned itself with the work of Canguilhem and his intellectual lineage, can be summarized as one of illuminating the nonsubjective conditions of concept formation and all subsequent conceptual activity. "Reason," Foucault asserted in one of his later articulations of how he had distanced himself from phenomenology, "is self-created" (1983/1988, 28-29). Reason itself creates reason. Reason, rationality, and the capability for concept formation (what might be termed "conceptuality") that enable them, as well as the knowledge they produce, look only to their own inner life, to their own epistemic foundations, modifications, oppositions, creations, and engenderings for their vitality and significance. They live 
by force of their own "personalities"18 — not by that of individual embodied human subjects. Modern subjects, in this perspective, served conceptual purposes. They did so by uttering statements that "enunciated" reason's self-guided ways of processing intelligence (Alcoff 2005, 215216; Foucault 1969/1982, 88-105).

Reason, in sum, in Foucault's conceptualist regard, was not dominated by empirical human beings. This perspective gave Foucault's work on the history of scientific rationality an independence from what otherwise might have been seen as determining psychological, environmental, or evolutionary factors. It was to prove highly advantageous for Foucault's particular style of analytical interpretation on his chosen scientific subject matter. However, it was also to cast a perpetual shadow over the empirical human being-the figure that, in the era of modernity, could only be conceived for Foucault in phenomenological terms. It placed this embodied, living character in an essentially negative theoretical light.

From this point on, the empirical human subject of modernity, stripped of epistemic capability, could acquire definition only as an organism that is born and dies, but does not otherwise process intelligence-or proceed intelligently-except via various forms of enunciate-able reasoning, be they gentle or severe, barbaric or modern, punitive or honorary. From this point on, the living, moving human body could come to be regarded as nothing of significance other than a materiality that manifested intelligent forces other than its own. It could be analyzed - at least in modern contexts - as a finite keeper of a soul born wholly out "of methods of punishment, supervision and constraint" (Foucault 1975/1995, 29). ${ }^{19}$ This conceptualist definition of the empirical embodied human being is nowhere more intensely characterized than in the work that is among the most often cited in dance analysis: Surveiller et punir.

Here, then, lay the crucial difference between the approaches in which Foucault had been trained: the difference between a philosophy oriented by the activity of living intelligently through events, processes, places, subjects, and objects, many of them human, and a philosophy oriented by general ideas and conceptuality-albeit a conceptuality that was not without material aspects of its own. ${ }^{20} \mathrm{It}$ was a difference, as May summarizes it, of agentive identity with respect to the performance of epistemic processes - the difference of whether human beings enact performatively the constitution of knowledge or whether knowledge constitutes them $(2005,305)$. Foucault, intent on dealing directly with the linguistic as well as the unconscious dimensions of scientific thought in history, was attracted to the latter. Canguilhem's work provided him with a methodological alternative to the approaches of phenomenology, which were, albeit variously, anchored in the former (Gutting 2005a, 61-64).

As Canguilhem himself characterized Foucault's orientation, the turn Foucault made away from phenomenology ultimately was one in which the traditional, subject/object-centered question, "What does it mean to think?" was replaced by the linguicentric question, "What does it mean to speak?" $(1966 / 2005,76)$. Thinking was left to the conceptual realm itself. The primacy of experienced, embodied, but object-oriented, transcendental consciousness was replaced by the primacy of historicized conceptuality. Those who might subsequently contest that replacement would henceforth be consigned to the ranks of the pre-critically naïve.

In this regard, a Foucaultian conceptualist perspective implies that dance inquiry can and indeed must depart from its dancing subjects, its living, experiencing corporeal beings, in order to maintain an intellectual relation to them. It must deny recognition of any non-enunciative, embodied, intelligently performative presence in order to pursue critical interpretive analytics.

The shadow cast by Foucault's turn to conceptualism can be seen to pre-figure or enable to some extent the early Foucault's dystopic view of the living human organism - the view that casts the corporeal being in general as a kind of prison to which a given person's thought, or soul, is 
"condemned" (Foucault 1975/1995, 3-31; Franko, 2011). The perspective begins with the conceptualist assumption that an embodied condition a priori is a problematic and marginalized condition, not simply because historical conditions tend to make it so (i.e., to make it unhealthy, unequal, unsafe, unwell), but, even more basically, because embodiment is in and of itself an inherently negative epistemological reality. It is posited as a primordially unknown condition, a way of being that does not know, yet lives. It is not where the intellectual action is, ontologically speaking, in relation to conceptual processes. In terms of reasonableness, it is the dark place of the self.

In this dystopic regard, following early Foucault's anti-phenomenological turn would entail accepting the general assumption that the embodiment of conventional symbolic processes is always moving within an "epistemology of suspicion," since such processes are fundamentally alien to the organism into which they are inscribed (Gutting 2005a, 109). It would mean accepting as given the claim that an individual's investment in technically defined (conventionally "disciplined") corporeal practices amounts always and only to a sacrifice, repression, or oppression of the vitality, freedom, and autonomous character of that human being. Faced with this implication, it would seem to be the distinctive ethical charge of dance inquiry not to follow Foucault's lead into such a conceptualist/rationalist critical project, given that dance practices in so many cases celebrate, as opposed to negate or constrain, the reality (as opposed to the representation) of embodiment's epistemological capabilities, and do so in ways that are both enabled, and also sanctioned, by convention.

\section{Conclusion}

As has been emphasized throughout this examination, Foucault's interests for rejecting phenomenology and adopting a conceptualist approach were anything but rooted in an interest in danced or choreographic subjects, objects, movements, or beings. Starting from dance, or even from the being of motility more generally, is not where Foucault started. Dance, or any embodied movement-oriented practice, is not what Foucault studied. His early objects of analysis-madness, the classifications of natural science, and incarceration, among others-were profoundly different. They were not understood to originate in, or evolve intelligently via, corporeal or experiential motility_precisely not.

It is a telling fact, in this regard, that, when Foucault drew his key historical division between modern and pre-modern forms of punishment in the opening chapter of Surveiller et punir, he did so in terms of a concept of the living human body (corps) that disregarded its inherent motility to a nearly absolute extent, and took this absenting characterization entirely for granted. Modern forms of punishment, Foucault argued, were equated with "non-corporal" ("incorporel") or "bodiless" ("sans corps") forms of penalizing, while earlier, non-modern forms of penalizing were defined as "corporal" ("corporel"; 1975, 21-22; 1975/1995, 15-17). The difference between the corporal and the non-corporal, in Foucault's analysis, was that bodiless forms entailed "merely" imprisonment ("pure privation de liberte"; 1975, 21; 1975/1995, 15). That is to say, non-corporal punishments, in his view, were those that imposed a loss of motility alone. What made a form "corporal" was the infliction of pain. The distinction assumed, in other words, that the punishment of restricting the movement of a human subject lacked corporeal significance. Confinement in and of itself was not posited by Foucault as taking a bodily toll on the imprisoned (any more, perhaps, than sitting day in and day out in a library did). The only way in which punishment acquired bodily meaning was in the damaging of the body's flesh. It would be difficult to find a clearer way in which to show an absence of dance-attuned consciousness than that which is evident in this analytical perspective. The constraining of motility — no matter what the degree of severity—may be understood as anything but "non-corporal" from virtually any point of view that could be identified as choreographic or dance-based. 
In this specific regard, Foucault's initial turn away from phenomenology and towards his particular form of critical conceptualist analysis would seem to align his thought at this relatively early stage of his career (indeed, later stages would call for their own examination) with those theorists in both the humanities and social sciences against whom dance scholars in the recent past have felt it necessary to write most actively. It aligns with those who failed to recognize that the body of dancing is, before all else, a moving form of organismic life, not an inert mass of organs, flesh, and bones. It aligns with those who have passed over the investigation of what must be understood as the distinctive motility embodied in choreographic phenomena-the motility that no other art or communicative phenomena might exhibit or realize. It aligns with those who have relied uncritically on conventional, linguicentrically theorized discourses that cast the practice and execution of danced movement as either transparently or mechanistically representing intelligence other than its own and capable of nothing more.

It would appear from these observations, then, that to take a Foucauldian turn with regard to phenomenology would entail very negative implications for dance inquiry. However, the questions articulated throughout this examination in relation to his rejection suggest a somewhat less uniform outcome. Certainly, the phenomenological definition of the observing, object-oriented, knowledgeoriginating subject that Foucault rejected would be one that dance specialists might well be equally hesitant to embrace. In addition, Foucault's dissatisfaction with the limits of phenomenological theory in regard to its capacity to interface fluently with discourse theory-or with any method of symbolic analysis for that matter-might also be a dissatisfaction that dance specialists would share and seek to address critically. Such parallels notwithstanding, however, it remains crucial not to ignore the fundamentally different relation of subjectivity to experiences of movement and characters of motility that the human beings of dance (even modern ones) are generally understood to embody, often consciously. Such relations define the intellectual activity of dance artists in ways that contrast sharply with those of the phenomenological subjects that Foucault conceptualized and found inherently inconsequential for his purposes. Simply put, the dancing or choreographing subject's consciousness is dissimilar to that Foucault assumes for the phenomenological subject of science because the dancing human being exists in a moving reality-in a realm of being that affords continuously changing intelligence. This lies at the heart of the difference between the identity of the dancing subject and that of Foucault's phenomenological homme. The motile human being does not invent continuous consciousness via an appeal to some inevitably fallacious transcendental theory. Human beings register a continuity of changing relations of intelligence as they actually move through their dynamic environment.

In this regard, the implication of Foucault's turn away from phenomenology that is most crucial to consider critically would be the implication that to accept his critique of phenomenology entails accepting his claim that an analytics of finitude defines the human subjects of modernity. This analytic gives definitive priority to the origin and termination of the human being rather than to the movements occurring through and throughout its lifespan-processes that define its spatiotemporal continuity, not its finitude. The dancing or choreographing human subject, to the extent that it is in evidence when it is in movement, cannot emerge from such an analytics of finitude.

It now begins to seem clear why dance as a subject was not recognized in Foucault's early critical projects. It could not be without a rethinking of the analytic that defined the entire history of the modern era. An alternate analytics, an analytics of motility, would have to be conceptualized in relation to a historical project that might encompass the subject of dance. Even more divergent, an entirely different kind of analytics might have to be conceptualized-one that entertained the possibility of ahistorical, originary analytical movements - an emergent analytics specific to a significatory realm brought into being in the performance of dance itself.

In sum, the implications of following Foucault's initial anti-phenomenological turn into archaeological and genealogical forms of historical/philosophical/critical inquiry are well worth 
consideration for scholars of dance. The benefits of his particular brand of interpretive analytics that develops from this early turn would seem to come at a relatively high intellectual price, given the particular array of human beings and the particular kind of human subject matter to which the field of dance inquiry, by its own definition, gives priority. It is the price of choosing conceptuality as the sole basis for understanding how human beings do, and might possibly, dance. It is the price of denying actual embodied experience, subjective, pre-subjective, or ecological, as anything but a pre-critical, naïve starting point for culturally focused inquiry. Finally, it is the price of always already giving priority to historical concerns-however genealogically attuned, temporally multiple, or presently situated they might be-when interpreting an art form that has the capacity to move creatively and concurrently, not only in relation to the past, but to the future as well.

Of course, the pragmatic gains that dance studies has made in adopting Foucault-any Foucault, early, late, or otherwise-also have been considerable. The field has acquired its fair share of crossdisciplinary prestige that any alignment with Foucault's work inevitably carries. It has also benefited from the new, more politically engaged identity that the adoption and deployment of Foucauldian theory-any aspect of it-has produced. A diverse array of interdisciplinary allies-fields such as cultural studies, gender studies, American studies, critical race studies-have been cultivated to no small extent on the basis of the theoretical investment that dance studies has made in Foucault. However, for dance studies to follow Foucault's critical orientation toward phenomenological approaches, broadly conceived, amounts to sacrificing one of the field's own greatest analytical and critical faculties - its capacity to attune articulately to the generative, structuring significance of bodily motility. To turn away from Foucault, in this regard, is not necessarily to forsake the position of the engaged critic of social injustice. It is to recognize that his theories articulate only an incomplete array of possibilities for adopting that position, and that the possibilities they do articulate do not, perhaps, themselves do justice to all that it can mean and be to dance and to choreograph.

\section{Notes}

Humble acknowledgement is due to Mark Franko for his exceptional patience, editorial inspiration, and support, and to the two reviewers whose comments (hopefully) helped me to avoid making at least a few of the worst possible mistakes. Thanks also to Erich Reck, Carrie Noland, and Anthea Kraut whose encouragement and scholarly assistance were invaluable.

1. See Desmond $(1997,3)$ for a similar assessment. Desmond dates the emergence of a Foucauldian approach in dance theory to the 1980s. Susan Foster's pioneering text, Reading Dancing (1986), which includes "an archeology of dance" modeled on Foucault's early critical theory, may be seen as a seminal example of Foucault's adoption in dance theory (Foster 1988, 248n.2). For an example of the recent use of Foucault, see Reed (2010). Foucault is not directly cited in this work. However, Reed makes reference to the "disciplining" of Kandyan dance that occurred when it underwent a process of classicization in connection with the rise of Sinhala nationalism in Sri Lanka $(2010,152)$. Via the use of scare quotes, Reed makes an oblique reference to Foucault. Hahn (2007) and O'Shea (2007) provide similar examples, making brief reference to Discipline and Punish. Dance theorists who have focused specifically on issues of gender and sexuality and who have drawn on Volume 1 of Foucault's Histoire de la sexualité (History of Sexuality, Vol. I, 1976) include Cowan (1990), Martin (1990), Foster (1988, 1996), Desmond (1993), Thomas (1996), Morris (1996), Burt (2001), and Nayfack (2010). This list, however, only begins the task of recognizing work that could be cited in this regard.

2. See May's analysis of Foucault's publication record as it evidences this change in his orientation (2005, 284-311). See also Charles Ruas's interview with Foucault, in which Foucault's "break" with phenomenology is identified with his 1955 move to Sweden $(1986,174)$. François Dosse, likewise, identifies Foucault's critique as having begun to develop between 1955 and 1960 
while he was writing Folie et déraison (Madness and Civilization), but reaching full expression only in the 1960s. Dosse characterizes Foucault's critique as "the final blow to the phenomenological project" in France $(1997,41)$.

3. Foucault's own comments cited in Eribon to some extent support this characterization $(1991,21)$.

4. May's assessment, it should be noted, is not without its opponents. However, with regard to the relatively early texts that have been most at issue for dance theory (Les Mots et les choses, Surveiller et punir, and, to a lesser degree, L'Archéologie du savoir, the essay "Nietzsche, Genealogy, History" [1971/1998], and Histoire de la sexualité I), May's evaluation is compelling. Dosse presents a similar view, stating that the phenomenological subject was "eliminated" from Foucault's project with the publication of Les Mots et les choses (1997, 41-42).

5. Foucault's theories have met with critical attention from a number of leading dance theorists: Franko (2010), Burt (2004), Lepecki (2006), Martin (1990), and Foster (1995), among others. However, differences with Foucault's theories are generally couched in muted terms. Lepecki characterizes his theoretical approach as a "supplement" to both Foucault and Derrida (2006, 8). William Sax expresses "reservations" about Foucault's social construction (2002, 6-7). Although Burt claims that Foucault's genealogical approach has limitations for dance theory (and details Butler's critique of Foucault), his analysis is written in terms that cast it as an extension of Foucault's genealogical approach (2004, 33-34). Martin characterizes his work as compelled in part by limitations evident in Foucault's approach to the body-which he claims Foucault sees "only from above." However, he adopts Foucaultian views of subjugation and the domination of bodies advanced in Surveiller et punir (1990, 45, 49-50). Foster's critical remarks on Foucaultian theories of power are phrased in the form of unanswered questions $(1995,15)$.

6. Eribon speculates along these lines that the Bibliothèque Nationale was "no doubt the one place in which Foucault spent the most hours of his life" (1991, 40).

7. Gutting, among others, calls attention to the very limited information that is available about many areas of Foucault's life history and cautions against interpretive analyses that read Foucault's texts and theories against his life (2005b, 23).

8. Macey reports that efforts were made during annual family vacations taken by the sea to instruct Foucault in the game of tennis, but these proved unsuccessful due to problems with Foucault's vision (1993, 1-20). Eribon notes that Foucault, while he was living in Tunisia during the late 1960s, enjoyed taking long, fast, and energetic walks, sometimes with friends (1991, 188). This is the first reference Eribon makes to any kind of motile practice in Foucault's life.

9. Mark Franko, for example, has noted that, while Foucault asserts in Surveiller et punir that the emergence of an "art of the body" constitutes an exceptionally important moment in the history of disciplinary activity in the classical age of Western civilization, nothing other than a vague reference to such an art is ever made in Foucault's text (Foucault 1975/1995, 137; Franko, 2011). Franko also documents that Foucault's only direct comment on dance was made during a 1966 radio broadcast entitled, "Le corps utopique." In this broadcast, Foucault made mention of the dancer's body as being a "dilated" body ("corps dilatê"), which simultaneously registered in its movements both interior and exterior aspects of its given space of performance. In Franko's estimation, this dilated "body as medium" had the potential to resolve what Foucault identified as the "doubling" empirical/transcendental subject contradiction-a contradiction on which Foucault's main objection to phenomenology was based (Franko, 2011). Franko's analysis illustrates what in this essay is referred to as an "analytics of motility," which enables a more realistic conception of the subject of dance than the analytics of finitude characterized by Foucault is able to do. This discussion of dance in Foucault's broadcast, however, never impelled Foucault to do any subsequent writing on the topic.

10. Eribon brings out repeatedly Foucault's own sensitivity to the defining influence of such life experiences (1991). In particular, Foucault observed that World War II was a formative force in his early life, and that it may have shaped his abiding fascination with history. 
11. Dosse, similarly, quotes Les Mots et les choses, when seeking to define Foucault's phenomenological critique $(1997,42)$. Eribon characterizes the text as "haunted by Merleau-Ponty's negative presence. From beginning to end ... inspired and driven by polemics against Husserl's thought and Merleau-Ponty's interpretation of it" $(1991,157)$.

12. In the original:

... la modernité commence lorsque l'être humain se met à exister à l'intérieur de son organisme, dans la coquille de sa tête, dans l'armature de ses members, et parmi toute la nervure de sa physiologie; lorsqu'il se met à exister au coeur d'un travail dont le principe le domine et le produit lui échappe; lorsqu'il loge sa pensée dans les plis d'un langage tellement plus vieux que lui qu'il n'en peut maîtriser les significations ranimées pourtant par l'insistance de sa parole. (1966b, 328-29)

13. In the original: “... l'homme moderne ... n'est possible qu'à titre de figure de la finitude. La culture moderne peut penser l'homme parce qu'elle pense le fini à partir de lui-même" (1966b, 329).

14. See note 9 above.

15. Detailed analyses of Canguilhem's influence on and relationship to Foucault can be found in May (2005), Eribon (1991), and Gutting (1989).

16. See Todd May's citations of Foucault's comments in this regard (May 2005, 303). Foucault's comments were written in an introduction to Canguilhem's text, The Normal and the Pathological (1966/1978). They identify the branches described here as a "rupture." See Foucault's essay, "Life: Experience and Science," which is a modified version of the same introduction $(1985 / 1998)$.

17. Canguilhem identified a variety of objects studied by the history of science, including documents, instruments and techniques, methods, and questions, as well as "concepts to analyze and criticize" (1983/2005, 204). Canguilhem asserted, however, that it was only the study and analysis of concepts that conferred "the dignity of the history of science" upon the enterprise in which he was engaged $(1983 / 2005,204)$. Canguilhem's work focused on the circulation of such concepts. He wrote, for example, on the concepts of "regulation" and "the regulator," which appeared in a varied sequence of scientific work in theology, astronomy, technology, medicine, and sociology and eventually became key for the understanding of biological organization that was to develop in the twentieth century (Rheinberger 2005, 194). Following Canguilhem, Foucault focused his own historical project on concepts as well-the modern concept of l'homme or "man" foremost among them.

18. Canguilhem, in his famous essay defending Les Mots et les choses against criticism it had received from phenomenologically inclined authors, associated the text's thesis with a poem by Mallarmé in which a phrase is described as uttering itself and "living through its own personality" $(1966 / 2005,76)$.

19. In the original: "de procédures de punition, de surveillance, de châtiment et de contrainte" $(1975,34)$.

20. As Franko has demonstrated, Foucault's concept of discourse does include, in its notion of the enunciative function in particular, and in its historical orientation generally, a recognition of the material aspects of both utterances and of writing (Franko, 2010). In this regard, the conceptualist approach Foucault turned toward was not one that was absolutely or simplistically abstract or disembodied in character.

\section{Works Cited}

Alcoff, Linda Martín. 2005. "Foucault's Philosophy of Science." In Continental Philosophy of Science, edited by Gary Gutting, 211-23. Malden, MA: Blackwell Publishing.

Burt, Ramsay. 2001. "Dissolving in Pleasure: The Threat of the Queer Male Dancing Body." In Dancing Desires: Choreographing Sexualities On \& Off the Stage, edited by Jane C. Desmond, 209-42. Madison: University of Wisconsin Press.

- 2004. "Genealogy and Dance History: Foucault, Rainer, Bausch, and de Keersmaeker." In Of the Presence of the Body: Essays on Dance and Performance Theory, edited by Andre Lepecki, 2946. Middletown, CT: Wesleyan University Press. 
Canguilhem, Georges. 1966/1978. On the Normal and the Pathological. Translated by Carolyn Fawcett. Dordrecht: D. Reidel.

- 1966/2005. "The Death of Man, or Exhaustion of the Cogito?" Translated by Catherine Porter. In The Cambridge Companion to Foucault, edited by Gary Gutting, 74-94. Cambridge: Cambridge University Press.

. 1983/2005. "The Object of the History of Sciences." Translated by Mary Tiles. In Continental Philosophy of Science, edited by Gary Gutting, 198-207. Malden, MA: Blackwell Publishing.

Cowan, Jane. 1990. Dance and the Body Politic in Northern Greece. Princeton, NJ: Princeton University Press.

Desmond, Jane. 1993. "Dancing Out the Difference: Cultural Imperialism and Ruth St. Denis's 'Radha' of 1906." Writings on Dance 9: 40-54.

- 1997. "Introduction." In Meaning in Motion: New Cultural Studies of Dance, edited by Jane Desmond, 1-25. Durham, NC: Duke University Press.

Dosse, François. 1997. The Rising Sign, 1945-1966: Vol. 1, History of Structuralism. Translated by Deborah Glassman. Minneapolis: University of Minnesota Press.

Eribon, Didier. 1991. Michel Foucault. Translated by Betsy Wing. Cambridge, MA: Harvard University Press.

Foster, Susan Leigh. 1986. Reading Dancing: Bodies and Subjects in Contemporary American Dance. Berkeley: University of California Press.

—. 1995. "Choreographing History." In Choreographing History, edited by Susan Leigh Foster, 3-21. Bloomington: Indiana University Press.

- 1996. "The Ballerina's Phallic Pointe.” In Corporealities: Dancing, Knowledge, Culture, and Power, edited by Susan Leigh Foster, 1-24. New York: Routledge.

Foucault, Michel. 1961. Folie et déraison. Histoire de la folie à l'âge classique. Paris: Plon. (Madness and Civilization: A History of Insanity. Translated by R. Howard. New York: Pantheon, 1965.)

Foucault, Michel. 1963. Naissance de la clinique. Une archéologie du régard médical. Paris: Presses Universitaires de France. (The Birth of the Clinic. Translated by A. Sheridan. New York: Vintage, 1973.)

Foucault, Michel. 1966a/2009. "Le Corps Utopique, les Hétérotopies.” Paris: Nouvelles editions lignes, 2009: 9-20.

Foucault, Michel. 1966b. Les Mots et les choses. Une archéologie des sciences humaines. Paris: Gallimard.

- 1966/1973. The Order of Things: An Archaeology of the Human Sciences. A translation of Les Mot et les choses. Reprint ed. New York: Vintage Books.

- 1969. L'Archéologie du savoir. Paris: Gallimard.

- 1969/1982. The Archaeology of Knowledge and the Discourse on Language. Translated by A. M. Sheridan Smith. New York: Pantheon Books.

—. 1971/1998. "Nietzsche, Genealogy, History." In Michel Foucault: Aesthetics, Method and Epistemology, Translated by Robert Hurley and others, edited by James Faubion, 368-91. Vol. 2, Essential Works of Michel Foucault, 1954-1984, Paul Rabinow, series ed. New York: Free Press. - 1975. Surveiller et punir. Naissance de la prison. Paris: Gallimard.

1975/1995. Discipline and Punish: The Birth of the Prison, 2d ed. Translated by Alan Sheridan. New York: Vintage Books.

— 1976. La Volonté de savoir. Vol. I of Histoire de la sexualité. Paris: Gallimard. (The History of Sexuality, Vol. I: An Introduction. Translated by Robert Hurley. New York: Pantheon Books, 1978.)

—. 1983/1988. “Critical Theory/Intellectual History.” Interview with Gerard Raulet. Translated by Jeremy Harding. In Michel Foucault, Politics, Philosophy, Culture: Interviews and Other Writings, 1977-1984, edited by Lawrence D. Kritzman, 17-46. New York: Routledge.

- 1985/1998. "Life: Experience and Science." In Michel Foucault: Aesthetics, Method and Epistemology, translated by Robert Hurley and others, edited by James Faubion, 465-78. Vol. 2, Essential Works of Michel Foucault, 1954-1984, Paul Rabinow, series ed. New York: Free Press. 
Franko, Mark. 2010. "Body-Language and Language-Body in William Forsythe's Choreography: Michel Foucault and Louis Marin on the Baroque Body." ARS AETERNA-Unfolding the Baroque: Cultures and Concepts 2 (1): 84-101.

- 2011. "Archeological Choreographic Practices: Foucault and Forsythe." History of Human Sciences 24(4): 97-112.

Gutting, Gary. 1989. Michel Foucault's Archaeology of Scientific Reason. Cambridge: Cambridge University Press.

- 2005a. Foucault: A Very Short Introduction. Oxford: Oxford University Press. . 2005b. "Introduction, Michel Foucault: A User's Manual." In The Cambridge Companion to Foucault, edited by Gary Gutting, 1-28. 2nd ed. Cambridge: Cambridge University Press.

Hahn, Tomie. 2007. Sensational Knowledge: Embodying Culture through Japanese Dance. Middletown, CT: Wesleyan University Press.

Lepecki, André. 2006. Exhausting Dance: Performance and the Politics of Movement. New York: Routledge.

Macey, David. 1993. The Lives of Michel Foucault: A Biography. New York: Pantheon Books.

Martin, Randy. 1990. Performance as a Political Act: The Embodied Self. New York: Bergin \& Garvey Publishers.

May, Todd. 2005. "Foucault's Relations to Phenomenology." In The Cambridge Companion to Foucault, edited by Gary Gutting, 284-311. 2nd ed. Cambridge: Cambridge University Press.

Miller, James. 1993. The Passion of Michel Foucault. New York: Simon \& Schuster.

Morris, Gay. 1996. “'Styles of the Flesh': Gender in the Dances of Mark Morris.” In Moving Words: Rewriting Dance, edited by Gay Morris, 141-58. New York: Routledge.

Nayfack, Shakina. 2010. Butoh Ritual Mexicano/Alchemy Is Dancing. Saarbruchen, Germany: Lambert Academic Publishing.

O'Shea, Janet. 2007. At Home in the World; Bharata Natyam on the Global Stage. Middletown, CT: Wesleyan University Press.

Reed, Susan A. 2010. Dance and the Nation: Performance, Ritual, and Politics in Sri Lanka. Madison: University of Wisconsin Press.

Rheinberger, Hans-Jörg. 2005. "Reassessing the Historical Epistemology of Georges Canguilhem.” In Continental Philosophy of Science, edited by Gary Gutting, 187-97. Malden, MA: Blackwell Publishing.

Ruas, Charles. 1986. "Postscript: An Interview with Michel Foucault." In Death and the Labyrinth: The World of Raymond Roussel, translated by Charles Ruas, 169-86. New York: Doubleday.

Sax, William S. 2002. Dancing the Self: Personhood and Performance in the Pandav Lila of Garhwal. Oxford: Oxford University Press.

Schrift, Alan D. 2006. Twentieth-Century French Philosophy: Key Themes and Thinkers. Malden, MA: Blackwell Publishing.

Thomas, Helen. 1996. "Do You Want to Join the Dance? Postmodernism/Poststructuralism, the Body, and Dance." In Moving Words: ReWriting Dance, edited by Gay Morris, 63-87. New York: Routledge Press. 